\title{
Light-Driven Preparation, Microstructure, and Visible-Light Photocatalytic Property of Porous Carbon-Doped $\mathrm{TiO}_{2}$
}

\author{
Xiao-Xin Zou, ${ }^{1,2}$ Guo-Dong Li, ${ }^{2}$ Jun Zhao, ${ }^{2}$ Juan Su, ${ }^{1,2}$ Xiao Wei, ${ }^{1}$ Kai-Xue Wang, \\ Yu-Ning Wang, ${ }^{1,2}$ and Jie-Sheng Chen ${ }^{1}$ \\ ${ }^{1}$ School of Chemistry and Chemical Engineering, Shanghai Jiao Tong University, Shanghai 200240, China \\ ${ }^{2}$ State Key Laboratory of Inorganic Synthesis and Preparative Chemistry, College of Chemistry, Jilin University, \\ Changchun 130012, China
}

Correspondence should be addressed to Guo-Dong Li, lgd@jlu.edu.cn and Jie-Sheng Chen, chemcj@sjtu.edu.cn

Received 12 November 2011; Accepted 19 December 2011

Academic Editor: Xuxu Wang

Copyright (C) 2012 Xiao-Xin Zou et al. This is an open access article distributed under the Creative Commons Attribution License, which permits unrestricted use, distribution, and reproduction in any medium, provided the original work is properly cited.

\begin{abstract}
Highly porous carbon-doped $\mathrm{TiO}_{2}\left(\mathrm{C}-\mathrm{TiO}_{2}\right)$ has been prepared, for the first time, through a light-driven approach using crystalline titanium glycolate (TG) as the single-source precursor. Although the nonthermally prepared porous $\mathrm{C}-\mathrm{TiO}_{2}$ is amorphous, it shows a remarkable visible-light photocatalytic activity higher than that of nitrogen-doped $\mathrm{TiO}_{2}\left(\mathrm{~N}-\mathrm{TiO}_{2}\right)$ due to its significant surface area $\left(530 \mathrm{~m}^{2} / \mathrm{g}\right)$ and pore-rich structure. X-ray photoelectron, electron paramagnetic resonance, and UV-Vis diffuse reflectance spectroscopy reveal that the as-prepared porous $\mathrm{C}-\mathrm{TiO}_{2}$ photocatalyst contains $\mathrm{Ti}-\mathrm{O}-\mathrm{C}$ bonds which result in visiblelight absorption of the material at wavelengths less than $550 \mathrm{~nm}$. Furthermore, it is discovered that the Ti-O-C bonds in the asprepared $\mathrm{C}-\mathrm{TiO}_{2}$ is easily transformed to coke-type species under mild thermal treatment $\left(200^{\circ} \mathrm{C}\right)$. The resulting coke-containing porous $\mathrm{TiO}_{2}$ is an even better visible-light photocatalyst, almost twice as effective as $\mathrm{N}-\mathrm{TiO}_{2}$, because of its stronger visible-light absorption. The Ti-O-C and the coke-containing porous $\mathrm{TiO}_{2}$ materials follow two different mechanisms in the visible-light photocatalysis process for degradation of methylene blue.
\end{abstract}

\section{Introduction}

The elimination of hazardous organic pollutants from the environment has become a major and perennial issue. Heterogeneous photocatalysis proves to be a green and efficient approach to photodecompose organic pollutants by solar energy [1]. For this application, typical photocatalysts commonly used are semiconductor metal oxides and sulfides such as $\mathrm{TiO}_{2}, \mathrm{ZnO}, \mathrm{CdS}$, and $\mathrm{ZnS}$, among which titanium dioxide is regarded as the most promising material due to its chemical stability, nontoxicity, and low cost [2]. However, the widespread use of $\mathrm{TiO}_{2}$ is limited by its wide bandgap energy, which causes the catalyst to exploit only a very small proportion (about $3 \sim 5 \%$ ) of solar radiation. Therefore, it is highly desired to develop strategies of shifting the photoresponsive range of $\mathrm{TiO}_{2}$ to visible spectral region. One of the most efficient strategies is to dope the $\mathrm{TiO}_{2}$ compound with nonmetals. Since the pioneering work reported by
Asahi on nitrogen-doped $\mathrm{TiO}_{2}\left(\mathrm{~N}-\mathrm{TiO}_{2}\right)$ [3], nonmetaldoped $\mathrm{TiO}_{2}$ has attracted a great deal of attention [4-9], for the nonmetal doping can lead to formation of intragap localized states or bandgap narrowing, improving the visiblelight photocatalytic activity of the material considerably. In particular, carbon-doped $\mathrm{TiO}_{2}\left(\mathrm{C}-\mathrm{TiO}_{2}\right)$ turns out to be remarkably effective under visible-light irradiation [10-21], and there has been report that $\mathrm{C}-\mathrm{TiO}_{2}$ is even superior to $\mathrm{N}$ $\mathrm{TiO}_{2}$ in visible-light photocatalysis [21].

Introduction of porous structures, which increases the surface area of the photocatalyst to a great extent, is believed to be an effective approach to further enhance the photocatalytic performance of $\mathrm{C}-\mathrm{TiO}_{2}$. The large surface area in combination with the porous feature can facilitate the diffusion and adsorption of reactant molecules [22, 23], offer more surface-active sites [24, 25], and enhance lightharvesting [24, 25]. Moreover, the transfer path of photogenerated charges from bulk to surface can be shortened, and as 
a result, the recombination of the photogenerated charges is greatly suppressed [25].

To our knowledge, only a few reports have demonstrated the preparation of porous $\mathrm{C}-\mathrm{TiO}_{2}$ visible-light photocatalysts [26-31], and the carbon-doping was usually accomplished through calcination or hydrothermal treatment using organic species as the carbon sources. In this paper, we report a facile light-driven preparation route [32] that leads to the successful formation of highly porous $\mathrm{C}-\mathrm{TiO}_{2}$ material without any thermal treatment, using crystalline titanium glycolate (TG) as the single-source precursor. The as-prepared porous $\mathrm{C}-\mathrm{TiO}_{2}$ containing only $\mathrm{Ti}-\mathrm{O}-\mathrm{C}$ bonds exhibits distinct visible-light photocatalytic activity. In view of the amorphous feature of the as-prepared $\mathrm{C}-\mathrm{TiO}_{2}$, the superior photocatalytic activity can be attributed to the Cdoping in combination with the large surface area $\left(530 \mathrm{~m}^{2} / \mathrm{g}\right)$ of the solid, which is unprecedented among the $\mathrm{C}-\mathrm{TiO}_{2}$ photocatalytic materials reported so far. Furthermore, it is found that the carbon in $\mathrm{Ti}-\mathrm{O}-\mathrm{C}$ bonds in the as-prepared porous $\mathrm{C}-\mathrm{TiO}_{2}$ is transformed to coke species after mild thermal treatment, and the resulting coke-containing porous $\mathrm{TiO}_{2}$ shows visible-light photocatalytic performance, even superior over the as-prepared $\mathrm{C}-\mathrm{TiO}_{2}$. The photocatalysis processes for the $\mathrm{Ti}-\mathrm{O}-\mathrm{C}$ and the coke-containing porous $\mathrm{TiO}_{2}$ materials follow two different mechanisms.

\section{Experimental}

2.1. Materials. Absolute ethanol, ethylene glycol, titanium sulfate, urea, methylene blue (MB), and aqueous ammonia were purchased from Beijing Chemical Factory. All the reagents were of analytical grade and used as received. Titanium $n$-butoxide was purchased from Tianjin Guangfu Fine Chemical Research Institute. Deionized water was used throughout.

2.2. Synthesis of Titanium Glycolate (TG). The TG precursor was prepared on a large scale according to the reported procedure with minor modifications [33]. Typically, titanium $n$-butoxide $(15 \mathrm{~mL})$ was added to ethylene glycol $(150 \mathrm{~mL})$ and heated at $180^{\circ} \mathrm{C}$ for 2 hours under vigorous stirring to form the TG compound. After cooling down to room temperature, the white TG precipitate was washed several times with ethanol and dried in an oven at $60^{\circ} \mathrm{C}$.

2.3. Light-Driven Preparation of Porous $\mathrm{C}-\mathrm{TiO}_{2}$. The TG precursor $(4.0 \mathrm{~g})$ was dispersed in water $(400 \mathrm{~mL})$ and then exposed to the UV-light irradiation for $2 \mathrm{~h}$. After the irradiation, the color of the solid sample turned from white (TG) to intense blue because of the presence of $\mathrm{Ti}^{3+}$ [32]. Finally, the blue solid product was separated from the mixture and dried in air, the $\mathrm{O}_{2}$ molecules of which oxidize the $\mathrm{Ti}^{3+}$ to $\mathrm{Ti}^{4+}$. The obtained light yellow $\mathrm{TiO}_{2}$ product, designated $\mathrm{C}-\mathrm{TiO}_{2}(\mathrm{UV})$, was amorphous and porous on the basis of X-ray diffraction and adsorption measurement. The elemental analysis indicated that the content of carbon in the material was $1.08 \mathrm{wt} \%$. The UV-light source used in the experiment was a $400 \mathrm{~W}$ high-pressure mercury lamp (main output at $313 \mathrm{~nm}$ ).

2.4. Control Experiments. The as-prepared porous C$\mathrm{TiO}_{2}$ (UV) was heated at $200^{\circ} \mathrm{C}$ and $500^{\circ} \mathrm{C}$ in air for $2 \mathrm{~h}$, respectively, and the corresponding products were designated $\mathrm{C}-\mathrm{TiO}_{2}(200)$ and $\mathrm{TiO}_{2}(500)$. The brown sample C$\mathrm{TiO}_{2}(200)$ contained $0.86 \mathrm{wt} \%$ carbon, and the white sample $\mathrm{TiO}_{2}(500)$ was carbon-free on the basis of elemental analysis. The $\mathrm{N}-\mathrm{TiO}_{2}$ containing $2.3 \mathrm{wt} \%$ nitrogen was prepared through a previously reported method using urea as the nitrogen source [34], and more characterization results about this sample are provided (see XRD in Figure S1, UVVis in Figure S2, and XPS in Figure S3 in Supplementary Material available online at doi:10.1155/2012/720183).

2.5. Photocatalytic Activity. The photocatalytic activity was assessed in aqueous solution in a water-cooled quartz cylindrical cell. Generally, the reaction mixture in the cell was maintained at about $20^{\circ} \mathrm{C}$ by a continuous flow of water, and was illuminated with an external light source. The visiblelight source was a $500 \mathrm{~W}$ Xe lamp (main output $>400 \mathrm{~nm}$ ), with a glass optical filter used to cut off the short wavelength part $(\lambda<420 \mathrm{~nm})$.

The as-prepared $\mathrm{C}-\mathrm{TiO}_{2}(\mathrm{UV})$ photocatalyst $(0.3 \mathrm{~g})$ was mixed with an aqueous solution of methylene blue (MB) $\left(300 \mathrm{~mL}, 1 \times 10^{-5} \mathrm{~mol} / \mathrm{L}\right)$. The aqueous system was magnetically stirred in dark for at least $2 \mathrm{~h}$ to establish an adsorption/desorption equilibrium of $\mathrm{MB}$ on the particle surface of the material and then subjected to visible-light irradiation. Each reaction cycle lasted for about $4 \mathrm{~h}$ during which oxygen was bubbled through the solution. At given irradiation time intervals, a series of aqueous solution samples $(3 \mathrm{~mL})$ were collected and separated from the suspended catalyst particles for analysis. The concentration of the MB was determined on a UV-Vis spectrophotometer by monitoring its characteristic absorption at $665 \mathrm{~nm}$. For comparison, the photocatalytic activities of $\mathrm{C}-\mathrm{TiO}_{2}(200), \mathrm{TiO}_{2}(500)$, and $\mathrm{N}-\mathrm{TiO}_{2}$ were also measured under the same condition. The weights of all the catalyst samples were identical $(0.3 \mathrm{~g})$. Considering that MB can absorb visible light above $600 \mathrm{~nm}$, a cutoff filter $(\lambda>600 \mathrm{~nm})$ was used to ensure that only MB was excited, and as a result, there was no significant change in the $\mathrm{MB}$ concentration after $4 \mathrm{~h}$ irradiation even in the presence of $\mathrm{C}$ $\mathrm{TiO}_{2}(\mathrm{UV})$ or $\mathrm{C}-\mathrm{TiO}_{2}(200)$.

2.6. General Characterization. The powder X-ray diffraction (XRD) patterns were recorded on a Rigaku D/Max 2550 $\mathrm{X}$-ray diffractometer with $\mathrm{Cu} \mathrm{K} \alpha$ radiation $(\lambda=1.5418 \AA)$ whereas the TEM images were obtained on a JEOL JSM3010 TEM microscope. The UV-Vis diffuse reflectance spectra were recorded on a Perkin-Elmer Lambda $20 \mathrm{UV} / \mathrm{Vis}$ spectrometer, and the absorbance spectra were obtained from the reflectance spectra by means of Kubelka-Munk transformation. The IR spectra were acquired on a Bruker IFS $66 \mathrm{v} / \mathrm{S}$ FTIR spectrometer. The carbon contents of the obtained samples were determined through elemental analysis on a Perkin-Elmer 2400 elemental analyzer. The 


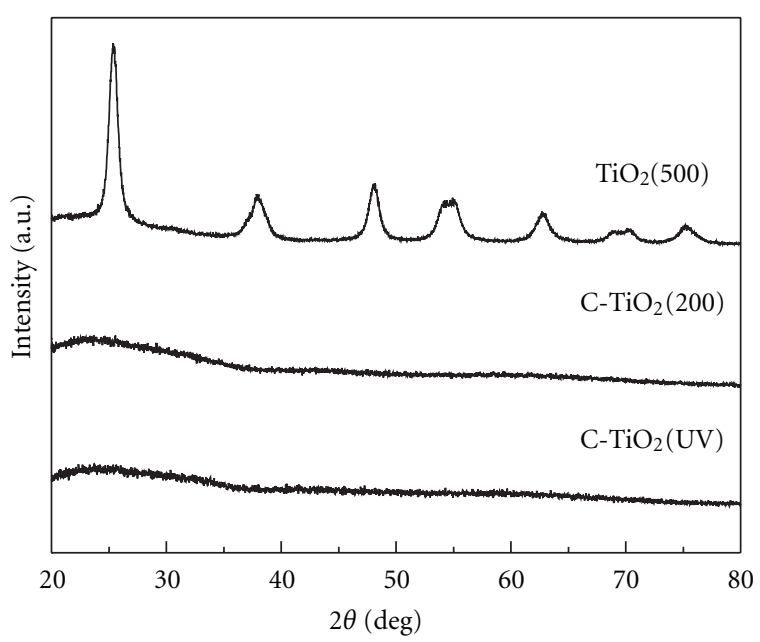

Figure 1: Powder XRD patterns of C-TiO 2 (UV), C- $\mathrm{TiO}_{2}(200)$, and $\mathrm{TiO}_{2}(500)$.

IR spectra were acquired on a Bruker IFS $66 \mathrm{v} / \mathrm{S}$ FTIR spectrometer whereas the X-ray photoelectron spectra (XPS) were recorded on a VG ESCALAB MK II electron spectrometer. The nitrogen adsorption and desorption isotherms were measured using a Micromeritics ASAP 2020 M system. The electron paramagnetic resonance (EPR) spectra were recorded on a JEOL JES-FA 200 EPR spectrometer. The concentration of MB was analyzed with a Shimadzu UV-2450 spectrophotometer.

\section{Results and Discussion}

3.1. General Structural Characterization. The powder X-ray diffraction (XRD) patterns of the as-prepared porous $\mathrm{TiO}_{2}$ photocatalysts are presented in Figure 1. The sample C$\mathrm{TiO}_{2}$ (UV) directly obtained by the light-driven technique is noncrystalline on the basis of the X-ray diffraction. After thermal treatment at $200^{\circ} \mathrm{C}$, the product, $\mathrm{C}-\mathrm{TiO}_{2}(200)$, is still dominated by an amorphous phase, whereas at $500^{\circ} \mathrm{C}$ the obtained material $\mathrm{TiO}_{2}(500)$ is identified as pure anatase. The broad XRD peaks for $\mathrm{TiO}_{2}(500)$ indicate that this material is composed of nanoparticles and the corresponding particle size, estimated by the Scherrer formula, is about $8 \mathrm{~nm}$.

The specific surface area and the pore structure of the porous $\mathrm{TiO}_{2}$ solids were evaluated through $\mathrm{N}_{2}$ adsorption measurements. In Figure 2, the $\mathrm{N}_{2}$ adsorption/desorption isotherms and the corresponding $\mathrm{BJH}$ pore-size distribution for the three samples are presented. It is seen that the $\mathrm{N}_{2}$ adsorption/desorption isotherms (Figure 2(a)) are characteristic type IV curves, demonstrating the presence of a porous structure in all the three materials. For $\mathrm{C}-\mathrm{TiO}_{2}(\mathrm{UV})$ and $\mathrm{C}-\mathrm{TiO}_{2}(200)$, the negligible hysteresis loop at high relative pressures $\left(P / P_{0}\right)$ indicates that the pore size of these two samples is uniform and small. This result is in agreement with the pore-size distribution measurement (Figure 2(b)), which shows a narrow pore-size distribution with average pore sizes of $1.8 \mathrm{~nm}$ and $2.6 \mathrm{~nm}$ for $\mathrm{C}-\mathrm{TiO}_{2}(\mathrm{UV})$ and
TABLe 1: Surface area, pore size, and pore volume of the $\mathrm{TiO}_{2}$ samples.

\begin{tabular}{lccc}
\hline Sample & $\begin{array}{c}\text { Surface area } \\
\left(\mathrm{m}^{2} \mathrm{~g}^{-1}\right)\end{array}$ & $\begin{array}{c}\text { Pore size } \\
(\mathrm{nm})\end{array}$ & $\begin{array}{c}\text { Pore volume } \\
\left(\mathrm{cm}^{3} \mathrm{~g}^{-1}\right)\end{array}$ \\
\hline $\mathrm{C}-\mathrm{TiO}_{2}(\mathrm{UV})$ & 530 & 1.8 & 0.3 \\
$\mathrm{C}-\mathrm{TiO}_{2}(200)$ & 340 & 2.6 & 1.2 \\
$\mathrm{TiO}_{2}(500)$ & 89 & 3.7 & 0.1 \\
$\mathrm{~N}^{-\mathrm{TiO}_{2}}$ & 89 & 8.2 & 0.2 \\
\hline
\end{tabular}

C- $-\mathrm{TiO}_{2}(200)$, respectively. Interestingly, the mild thermal treatment at $200^{\circ} \mathrm{C}$ results in not only obvious loss of BETspecific surface area (from 530 to $340 \mathrm{~m}^{2} \mathrm{~g}^{-1}$ ), but also an unusual increase of pore size (from 1.8 to $2.6 \mathrm{~nm}$ ) and pore volume (from 0.3 to $1.2 \mathrm{~cm}^{3} \mathrm{~g}^{-1}$ ) (Table 1 ). In general, surface area, pore size, and pore volume should decrease simultaneously after thermal treatment due to structural shrinkage. The increase of pore size and pore volume of our material after the thermal treatment may result from a structural rearrangement of pore wall of the porous $\mathrm{C}-\mathrm{TiO}_{2}$. For $\mathrm{TiO}_{2}(500)$, the $\mathrm{N}_{2}$ adsorption measurement leads to a BET surface area of $89 \mathrm{~m}^{2} \mathrm{~g}^{-1}$, a pore size of $3.7 \mathrm{~nm}$, and a pore volume of $0.1 \mathrm{~cm}^{3} \mathrm{~g}^{-1}$. Obviously, at this treatment temperature, the pore structure of the $\mathrm{TiO}_{2}$ material is damaged to a considerable extent although its crystallinity is increased significantly.

To further verify the presence of porous structures in the obtained $\mathrm{TiO}_{2}$ samples, TEM and HRTEM have been performed and the corresponding images are presented in Figure 3. The TEM images (Figure 3(a)-3(c)) reveal that both $\mathrm{C}-\mathrm{TiO}_{2}(\mathrm{UV})$ and $\mathrm{C}-\mathrm{TiO}_{2}(200)$ possess a uniform worm-like porous structure, while $\mathrm{TiO}_{2}(500)$ displays only an irregular porous structure formed by randomly arranged and interconnected nanocrystals. The lattice spacing in Figure 3(d), obtained by HRTEM, is about $0.352 \mathrm{~nm}$, which is in accordance with the distance between (101) crystal planes of the anatase phase.

3.2. Chemical Nature of Carbon Species. To elucidate the nature of the carbon species in the obtained porous $\mathrm{C}$ $\mathrm{TiO}_{2}$ photocatalysts, infrared (IR) spectroscopy has been performed in combination with electron paramagnetic resonance (EPR) and X-ray photoelectron spectroscopy (XPS).

The IR spectra of $\mathrm{C}-\mathrm{TiO}_{2}(\mathrm{UV}), \mathrm{C}-\mathrm{TiO}_{2}(200)$, and the precursor TG are shown in Figure 4. Upon UV-irradiation of TG, the IR absorption peaks related to organic species in the TG precursor almost completely disappear, and only a very weak absorption at $1067 \mathrm{~cm}^{-1}$, which is associated with the presence of a small quantity of Ti-O-C bonds, remains. The above observation indicates that UV-irradiation of TG leads to the removal of organic species form TG and the formation of a final product C- $\mathrm{TiO}_{2}(\mathrm{UV})$ with a nominal formula $\mathrm{TiO}_{2}$ and a small amount of Ti-O-C species. Further mild thermal treatment $\left(200^{\circ} \mathrm{C}\right)$ leads to complete elimination of the $\mathrm{Ti}-$ $\mathrm{O}-\mathrm{C}$ absorption. This result demonstrates that the Ti-O$\mathrm{C}$ bonds in $\mathrm{C}-\mathrm{TiO}_{2}(\mathrm{UV})$ are not thermally stable, and can 


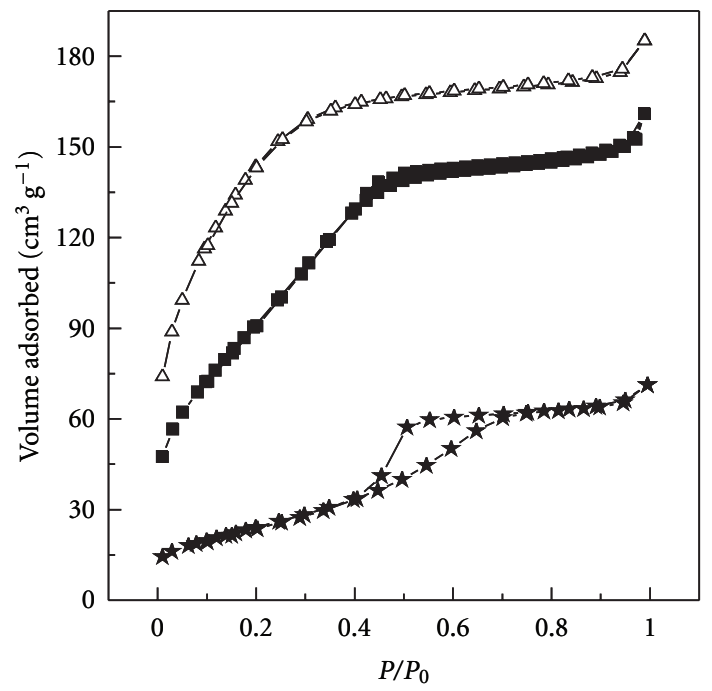

(a)

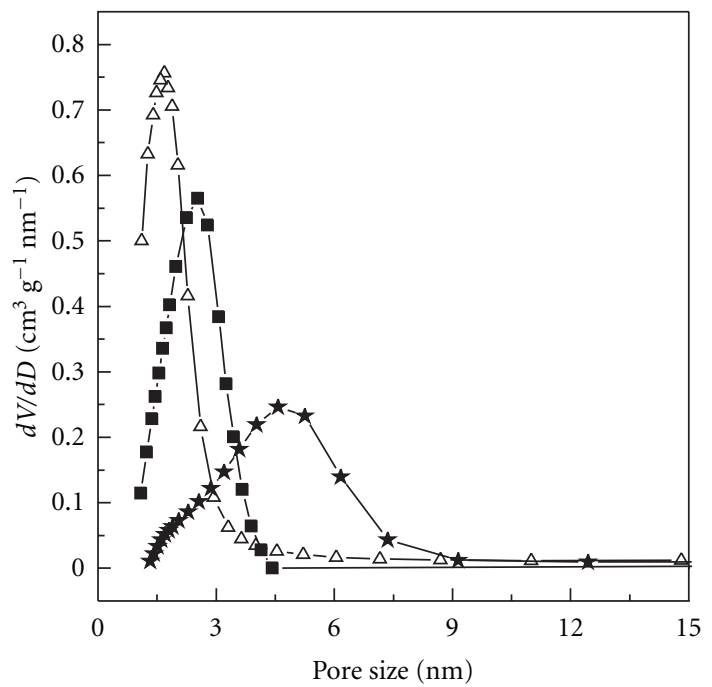

(b)

Figure 2: (a) $\mathrm{N}_{2}$ adsorption/desorption isotherms and (b) the corresponding BJH pore size distributions of $(\Delta)$ C-TiO $2(\mathrm{UV})$, $(\mathbf{\square})$ C$\mathrm{TiO}_{2}(200)$, and $(\star) \mathrm{TiO}_{2}(500)$.

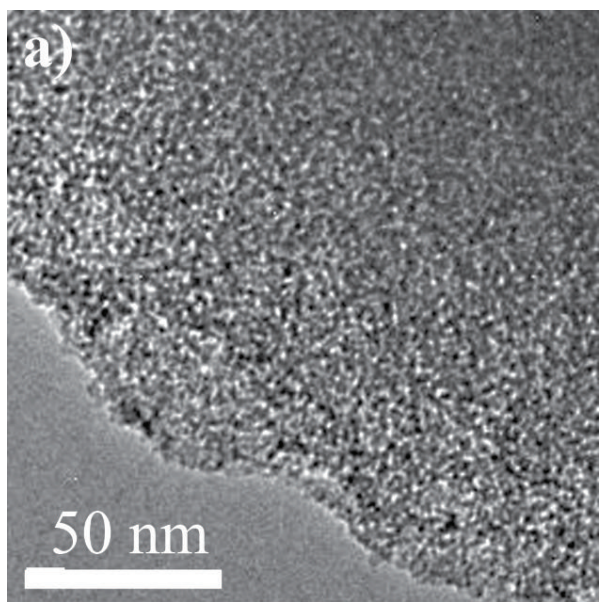

(a)

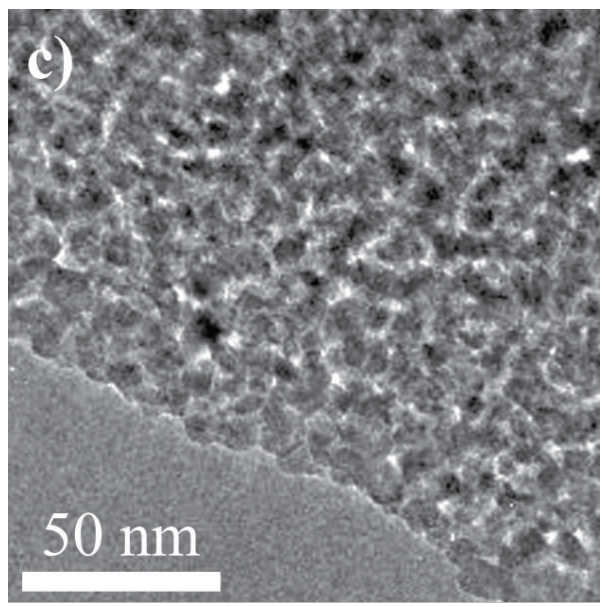

(c)

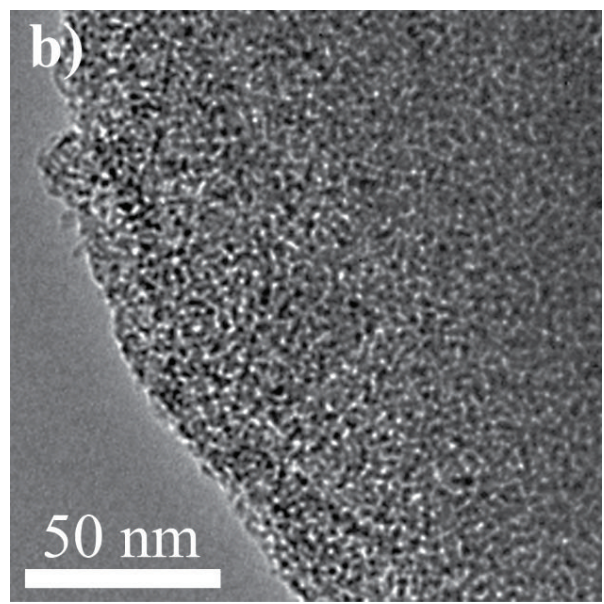

(b)

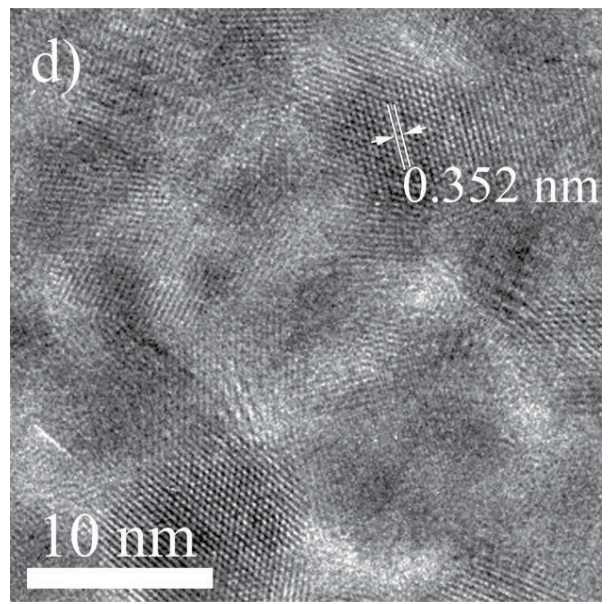

(d)

Figure 3: TEM images of (a) C-TiO $2(U V)$, (b) C-TiO 2 (200), (c) $\mathrm{TiO}_{2}(500)$, and (d) HRTEM image of $\mathrm{TiO}_{2}(500)$. 


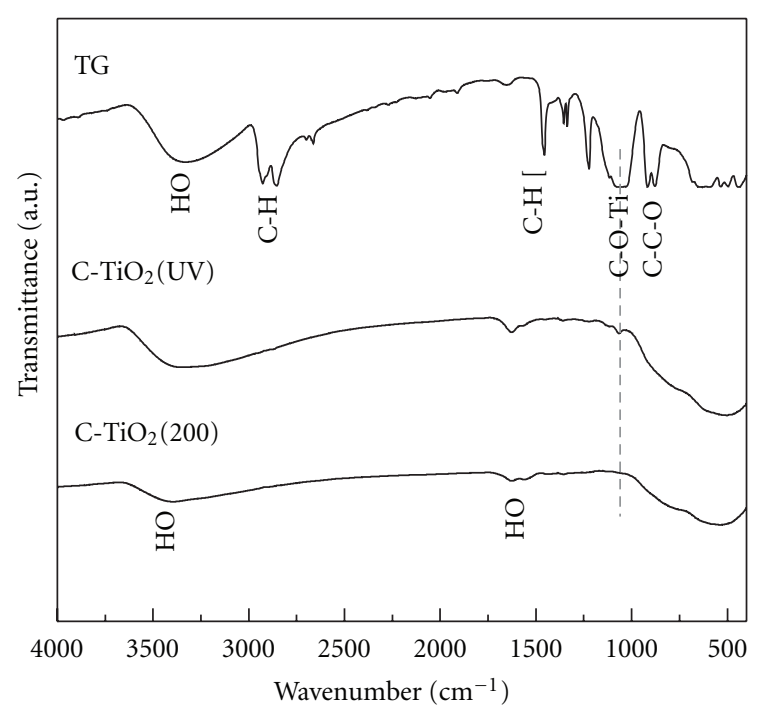

Figure 4: The IR spectra of TG, C- $\mathrm{TiO}_{2}(\mathrm{UV})$, and C-TiO $2(200)$.

be easily transformed to other forms of carbon in the $\mathrm{TiO}_{2}$ material.

The X-ray photoelectron spectroscopy (XPS) has been used to obtain valuable information about the chemical nature of surface elements for the $\mathrm{C}-\mathrm{TiO}_{2}$ materials. Figures 5(a) and 5(b) show the high-resolution $\mathrm{C}$ 1s spectra of $\mathrm{C}-\mathrm{TiO}_{2}(\mathrm{UV})$ and $\mathrm{C}-\mathrm{TiO}_{2}(200)$ samples. The peak at $284.8 \mathrm{eV}$ for both samples are due to adventitious elemental carbon from the XPS instrument [28], and this peak is also observed for the carbon-free $\mathrm{TiO}_{2}(500)$ sample. Besides the peak at $284.8 \mathrm{eV}$, a shoulder peak associated with $\mathrm{Ti}-$ O-C bonds at about $285.9 \mathrm{eV}$ is detected for $\mathrm{C}-\mathrm{TiO}_{2}(\mathrm{UV})$. Furthermore, no peaks appear at around $282 \mathrm{eV}$ (Ti-C bonds) and $288.5 \mathrm{eV}$ ( $\mathrm{C}=\mathrm{O}$ bonds), suggesting that except for Ti-O-C bonds, neither $\mathrm{O}-\mathrm{Ti}-\mathrm{C}$ bonds nor carbonate species are present in $\mathrm{C}-\mathrm{TiO}_{2}(\mathrm{UV})$. After the mild thermal treatment (at $200^{\circ} \mathrm{C}$ ), the peak of $\mathrm{Ti}-\mathrm{O}-\mathrm{C}$ bonds disappears, and only two weak peaks ascribed to $\mathrm{C}-\mathrm{O}(286.4 \mathrm{eV})$ and $\mathrm{C}=\mathrm{O}(288.5 \mathrm{eV})$ bonds are observed for $\mathrm{C}-\mathrm{TiO}_{2}(200)$. The simultaneous presence of $\mathrm{C}-\mathrm{O}$ and $\mathrm{C}=\mathrm{O}$ bonds was considered to be characteristic of carbonate species previously, but the carbonate species were not chromophores in nature [35]. Thus, the strong visible-light response of the brown C$\mathrm{TiO}_{2}(200)$ may arise from other carbon species, which were not detected by XPS. Figure 5(c) shows the high-resolution XPS spectra of Ti2p for $\mathrm{C}-\mathrm{TiO}_{2}(\mathrm{UV}), \mathrm{C}-\mathrm{TiO}_{2}(200)$, and $\mathrm{TiO}_{2}(500)$. It is seen that the XPS spectrum of Ti2p for the $\mathrm{TiO}_{2}(500)$ sample exhibit two peaks at 464.4 and $458.8 \mathrm{eV}$, which are assigned to the $2 \mathrm{p}_{1 / 2}$ and $2 \mathrm{p}_{3 / 2}$ core level of $\mathrm{Ti}^{4+}$, respectively. In comparison with XPS peaks of the $\mathrm{TiO}_{2}(500)$ sample, an obvious peak shift towards high binding energy $(0.2 \mathrm{eV})$ in the Ti2p spectra of $\mathrm{C}-\mathrm{TiO}_{2}(\mathrm{UV})$ and $\mathrm{C}-\mathrm{TiO}_{2}(200)$ is observed. Similar peak shift was also observed in the O1s spectra of $\mathrm{C}-\mathrm{TiO}_{2}(\mathrm{UV})$ and $\mathrm{C}-\mathrm{TiO}_{2}(200)$, as demonstrated in Figure 5(d). $\mathrm{TiO}_{2}(500)$ gives an XPS peak related to $\mathrm{Ti}-\mathrm{O}-\mathrm{Ti}$ oxygen at $530.0 \mathrm{eV}$, whereas $\mathrm{C}-\mathrm{TiO}_{2}(\mathrm{UV})$ and $\mathrm{C}-$ $\mathrm{TiO}_{2}(200)$ exhibit this XPS peak at $530.3 \mathrm{eV}$. The above results indicate that the presence of carbon species affect the local chemical circumstances of surface elements $\left(\mathrm{Ti}^{4+}\right.$ and $\mathrm{O}^{2-}$ ), and strong interaction between carbon species and surface elements is present.

To reveal the nature of the remained carbon species in C$\mathrm{TiO}_{2}(200)$, EPR spectroscopy has been employed to examine the $\mathrm{C}-\mathrm{TiO}_{2}(\mathrm{UV})$ and $\mathrm{C}-\mathrm{TiO}_{2}(200)$ samples (Figure 6). No EPR signals for paramagnetic species are observed for C$\mathrm{TiO}_{2}$ (UV) whereas $\mathrm{C}-\mathrm{TiO}_{2}(200)$ shows a distinct singlet signal at $g=2.0023$ assignable to coke-type carbon species. Similar EPR signals have also been observed for other porous materials containing coke species [30, 36-38]. Taking into account the existence of coke in $\mathrm{C}-\mathrm{TiO}_{2}(200)$, it is believed that the weak signals of $\mathrm{C}-\mathrm{O}$ and $\mathrm{C}=\mathrm{O}$ bonds (Figure 5) observed in this case are derived from the coke through its partial oxidization during the thermal treatment [38]. The XPS signal for the coke itself should be located at $284.8 \mathrm{eV}$, covered by the adventitious elemental carbon peak from the XPS instrument, and thus cannot be distinguished. From the above results, it is easily concluded that the carbon species ( $\mathrm{Ti}-\mathrm{O}-\mathrm{C}$ bonds) in $\mathrm{C}-\mathrm{TiO}_{2}(\mathrm{UV})$ are driven off from the $\mathrm{TiO}_{2}$ framework during the mild thermal treatment, forming a new type of carbonaceous matter (coke), on the surface of the $\mathrm{C}-\mathrm{TiO}_{2}(200)$ material. The signal of coke disappears for the carbon-free $\mathrm{TiO}_{2}(500)$ sample, which is obtained after thermal treatment of $\mathrm{C}-\mathrm{TiO}_{2}(\mathrm{UV})$ at $500^{\circ} \mathrm{C}$ in air, as at this temperature the coke species is completely oxidized and removed from the solid sample.

3.3. Photoresponsive Range. The UV-Vis diffuse reflectance spectra (Figure 7) demonstrate that the light-yellow C$\mathrm{TiO}_{2}$ (UV) shows two optical absorption thresholds at $385 \mathrm{~nm}$ in the ultraviolet region and $550 \mathrm{~nm}$ in the visible region. In comparison, no visible-light absorption but an absorption threshold at $400 \mathrm{~nm}$ appears for the white $\mathrm{TiO}_{2}(500)$. The ultraviolet absorption thresholds for both C- $\mathrm{TiO}_{2}$ (UV) and $\mathrm{TiO}_{2}(500)$ correspond to the inherent bandgap absorptions of $\mathrm{TiO}_{2}$, and the small difference between these threshold values are due to the difference in crystal structure (amorphous for $\mathrm{C}-\mathrm{TiO}_{2}(\mathrm{UV})$, anatase for $\left.\mathrm{TiO}_{2}(500)\right)$. The visible-light absorption band between 400 and $550 \mathrm{~nm}$ for $\mathrm{C}-\mathrm{TiO}_{2}(\mathrm{UV})$ arises from the $\mathrm{Ti}-\mathrm{O}-\mathrm{C}$ bonds which form localized occupied states in the bandgap of $\mathrm{TiO}_{2}$, as predicted by density function theory (DFT) calculations [39]. The energies of these intragap states are higher than that of the top of the $\mathrm{TiO}_{2}$ valence band, and as a result, the electron transitions from these intragap states to the $\mathrm{TiO}_{2}$ conduction band absorb energies distinctly lower than the $\mathrm{TiO}_{2}$ bandgap, corresponding to visible-light radiation. For the UV-Vis diffuse reflectance spectrum of the brown C$\mathrm{TiO}_{2}$ (200), a broad and strong band covering the whole visible region appears and this absorption is attributed to the presence of coke-type species in the material.

3.4. Photocatalytic Performance. The photocatalytic performances of the obtained $\mathrm{C}-\mathrm{TiO}_{2}$ materials have been evaluated by testing the degradation of methylene blue (MB), which is often used as a model pollutant in semiconductor 


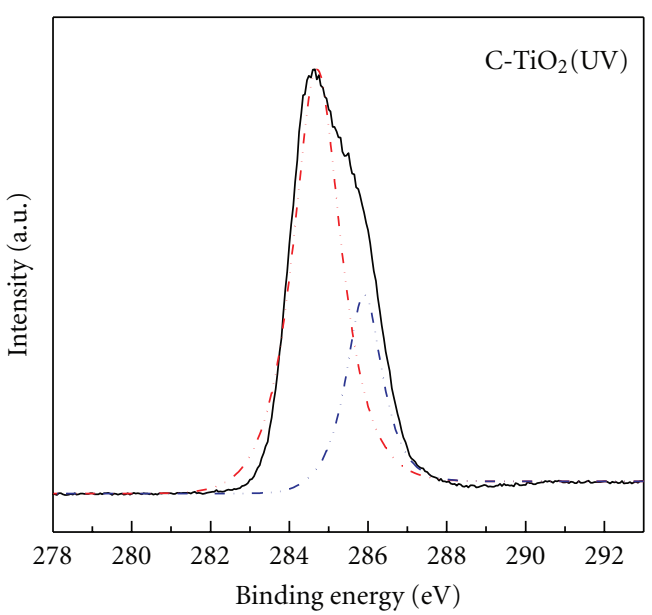

(a)

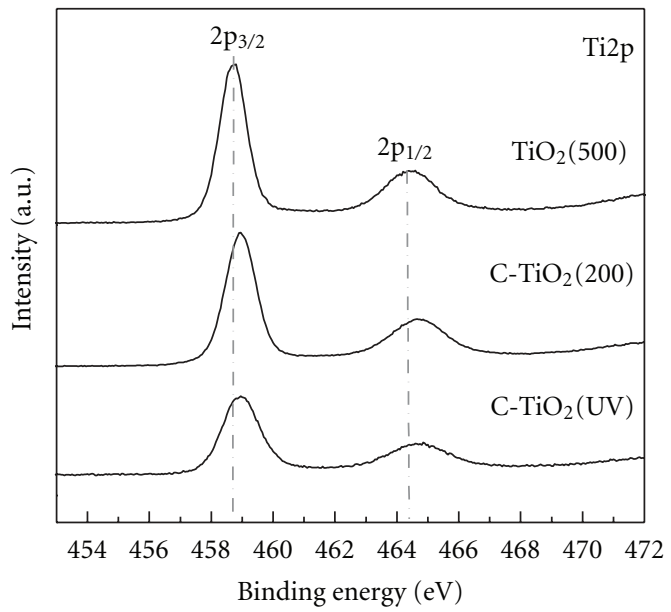

(c)

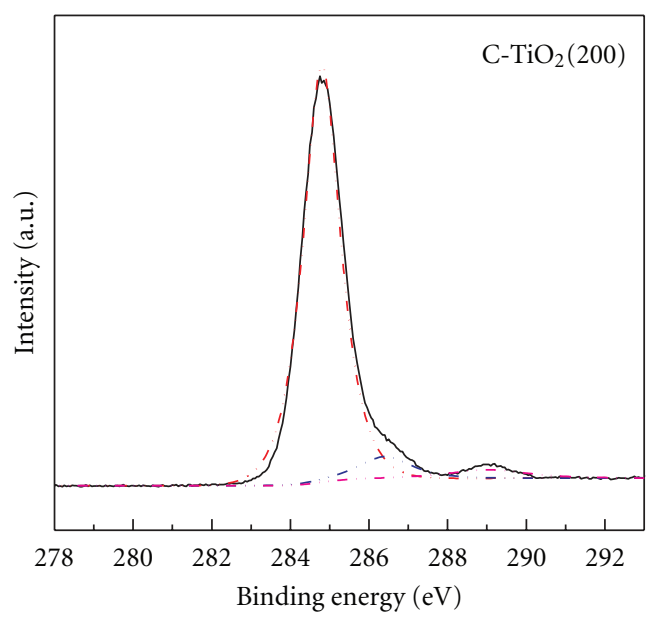

(b)

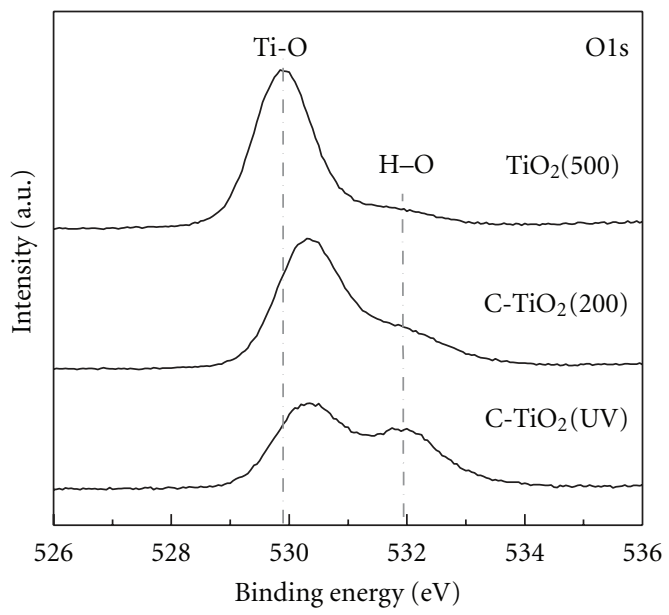

(d)

FIgURE 5: High-resolution XPS spectra of C1s for (a) C- $\mathrm{TiO}_{2}(\mathrm{UV})$ and (b) $\mathrm{C}-\mathrm{TiO}_{2}(200)$; high-resolution XPS spectra of (c) Ti2p and (d) Ols for $\mathrm{C}-\mathrm{TiO}_{2}(\mathrm{UV}), \mathrm{C}-\mathrm{TiO}_{2}(200)$, and $\mathrm{TiO}_{2}(500)$.

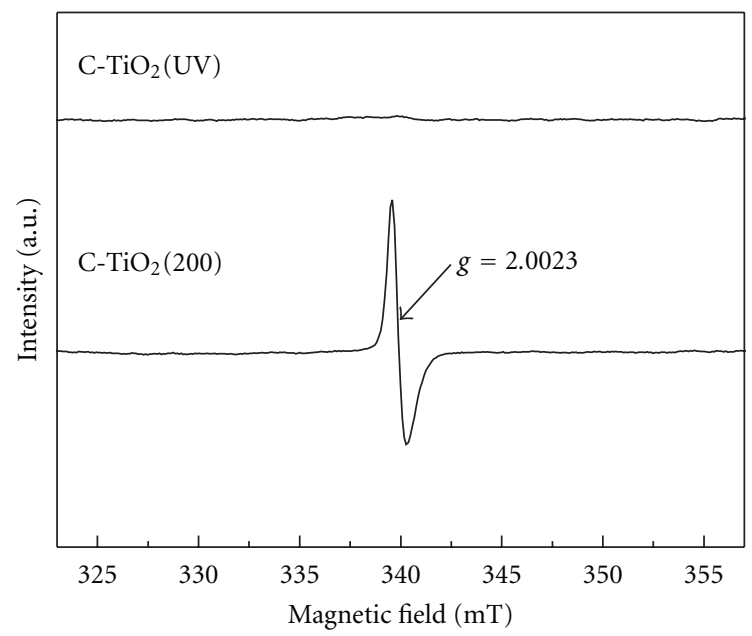

Figure 6: The EPR spectra of $\mathrm{C}-\mathrm{TiO}_{2}(\mathrm{UV})$ and $\mathrm{C}-\mathrm{TiO}_{2}(200)$ measured at room temperature.

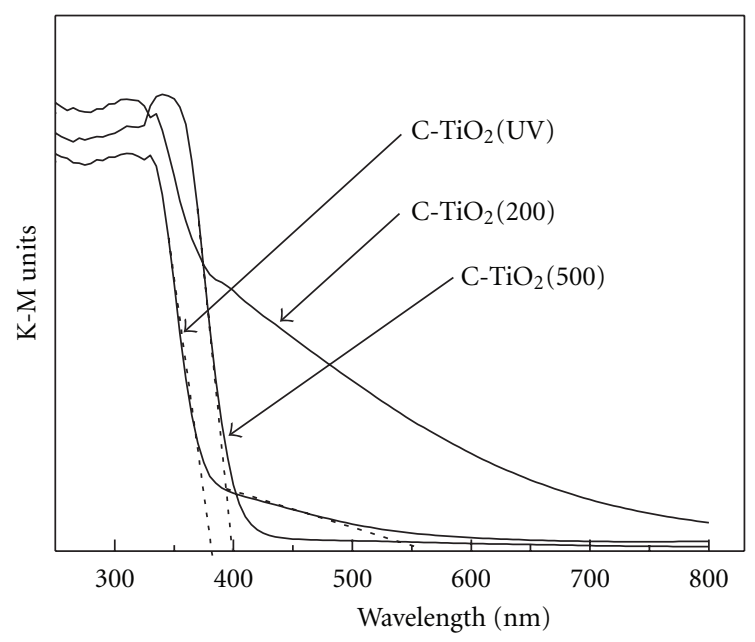

Figure 7: UV-Vis diffuse reflectance spectra of C-TiO ${ }_{2}(\mathrm{UV}), \mathrm{C}-$ $\mathrm{TiO}_{2}(200)$, and $\mathrm{TiO}_{2}(500)$. 


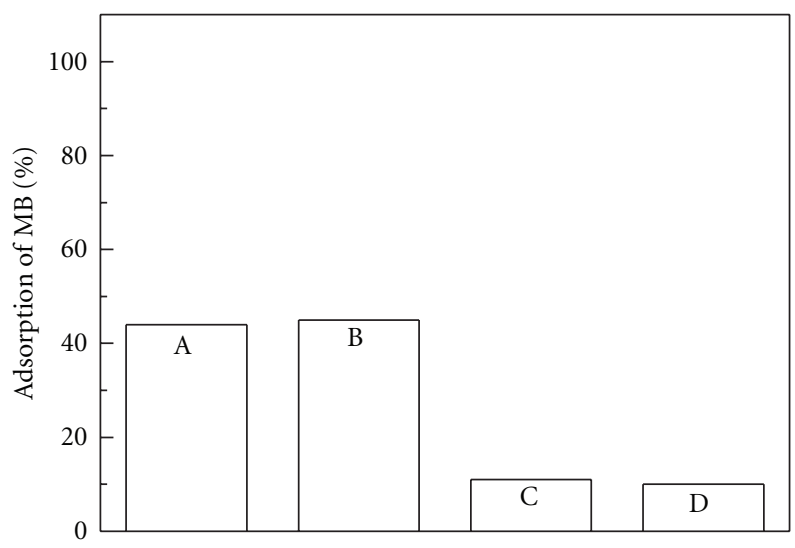

FIgure 8: The absorption capacity of (A) $\mathrm{C}-\mathrm{TiO}_{2}(\mathrm{UV})$, (B) C$\mathrm{TiO}_{2}(200)$, (C) $\mathrm{TiO}_{2}(500)$, and (D) $\mathrm{N}-\mathrm{TiO}_{2}$ for $\mathrm{MB}$.

photocatalysis, under visible light $(\lambda>420 \mathrm{~nm})$ irradiation. During the whole process of photocatalysis, the reaction system is saturated by oxygen, which can prevent $\mathrm{MB}$ from reduction to colorless leuco form (LMB) [40]. For comparison, the photocatalytic performance of $\mathrm{N}-\mathrm{TiO}_{2}$ has also been measured under the same condition.

It is generally believed that the capacity to adsorb reactant molecules on the surface of a solid material is a key parameter for its photocatalytic activity [41-43]. Therefore, the $\mathrm{MB}$ absorption capacities of the obtained samples were assessed before light irradiation, and the results are shown in Figure 8. The obtained sample $(0.3 \mathrm{~g})$ was mixed with an aqueous solution of methylene blue (MB) $(300 \mathrm{~mL}, 1 \times$ $\left.10^{-5} \mathrm{~mol} / \mathrm{L}\right)$. After the adsorption/desorption equilibration is reached, about $44 \%$ and $45 \%$ of the dye are removed from the respective aqueous solutions by adsorption on the $\mathrm{C}-\mathrm{TiO}_{2}(\mathrm{UV})$ and $\mathrm{C}-\mathrm{TiO}_{2}(200)$ surfaces, while only $11 \%$ and $10 \%$ of the initial dye are absorbed by $\mathrm{TiO}_{2}(500)$ and $\mathrm{N}-\mathrm{TiO}_{2}$, respectively. The high adsorption capacities for $\mathrm{C}-\mathrm{TiO}_{2}(\mathrm{UV})$ and $\mathrm{C}-\mathrm{TiO}_{2}(200)$ can be attributed to their significant surface areas $\left(530 \mathrm{~m}^{2} \mathrm{~g}^{-1}\right.$ for $\mathrm{C}-\mathrm{TiO}_{2}(\mathrm{UV})$, $340 \mathrm{~m}^{2} \mathrm{~g}^{-1}$ for $\left.\mathrm{C}-\mathrm{TiO}_{2}(200)\right)$. It is of interest to note that C$\mathrm{TiO}_{2}(200)$ shows an adsorption capacity similar to that of C$\mathrm{TiO}_{2}$ (UV) whereas the surface area of $\mathrm{C}-\mathrm{TiO}_{2}(200)$ is smaller than that of $\mathrm{C}-\mathrm{TiO}_{2}(\mathrm{UV})$. This unusual observation can be explained by the fact that the pore volume $\left(1.2 \mathrm{~cm}^{3} \mathrm{~g}^{-1}\right)$ of C$\mathrm{TiO}_{2}(200)$ is about 4-times as large as that $\left(0.3 \mathrm{~cm}^{3} \mathrm{~g}^{-1}\right)$ of C$\mathrm{TiO}_{2}(\mathrm{UV})$. In addition, it has been reported that coke matter contains polyaromatic structures $[30,36-38]$, and the $\pi-\pi$ interactions between coke and the aromatic rings of $\mathrm{MB}$ may also contribute to the adsorption of $\mathrm{MB}$ by the $\mathrm{TiO}_{2}(200)$ material.

The photocatalytic performances of the samples (Figure 9) are measured by the changes of MB concentration $\left(C_{t} / C_{0}\right)$ during the process of photodegradation reaction under visible-light irradiation $(\lambda>420 \mathrm{~nm})$, where $C_{t}$ is the concentration of $\mathrm{MB}$ at the irradiation time $t$ and $C_{0}$ is the initial concentration of $\mathrm{MB}$ after an adsorption/desorption equilibrium is reached before irradiation. $37 \%, 50 \%$, and $75 \%$ of $\mathrm{MB}$ are degraded after $4 \mathrm{~h}$ irradiation for

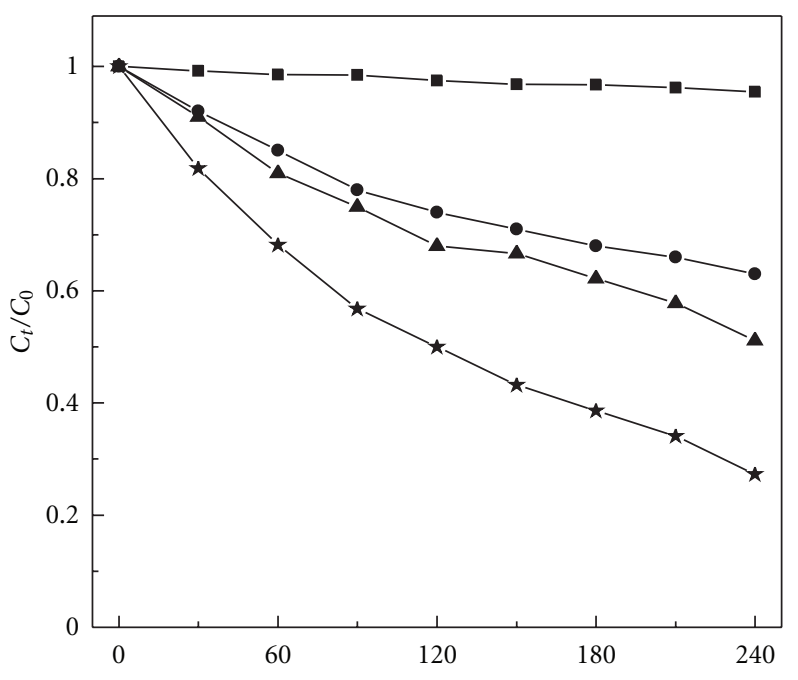

FIGURE 9: The residual fraction of $\mathrm{MB}$ in solution as a function of irradiation time with $(\boldsymbol{\Delta}) \mathrm{C}-\mathrm{TiO}_{2}(\mathrm{UV}),(\star)$ C- $\mathrm{TiO}_{2}(200)$, $\mathrm{TiO}_{2}(500)$, and $(\bullet) \mathrm{N}-\mathrm{TiO}_{2}$.

$\mathrm{N}-\mathrm{TiO}_{2}, \mathrm{C}-\mathrm{TiO}_{2}(\mathrm{UV})$, and $\mathrm{C}-\mathrm{TiO}_{2}(200)$, respectively. The photocatalytic activities of the two C-doped $\mathrm{TiO}_{2}$ materials are distinctly superior to that of the $\mathrm{N}-\mathrm{TiO}_{2}$ sample. In contrast, only slight degradation of $\mathrm{MB}(<5 \%)$ has been observed for $\mathrm{TiO}_{2}(500)$ after visible-light irradiation of 4 hours, indicating that the $\mathrm{TiO}_{2}(500)$ material is not a good visible-light photocatalyst. In addition, the difference of visible-light photocatalytic performances of the obtained $\mathrm{TiO}_{2}$ materials can be easily explained on the basis of the UV-Vis diffuse reflectance spectra of the samples (Figure 7). The coke-containing $\mathrm{C}-\mathrm{TiO}_{2}(200)$ and the $\mathrm{C}-\mathrm{TiO}_{2}(\mathrm{UV})$ with Ti-O-C bonds both absorb visible light, and consequently, they are visible-light responsive in the photocatalytic process. In contrast, the $\mathrm{TiO}_{2}(500)$ sample absorbs no visible light, and therefore this material is not photocatalytically active under visible-light irradiation. The higher photocatalytic activity of $\mathrm{C}-\mathrm{TiO}_{2}(200)$ in comparison with that of C$\mathrm{TiO}_{2}$ (UV) is rationalized by its stronger visible-light absorption. The recycling experiments demonstrate that both $\mathrm{C}-\mathrm{TiO}_{2}(\mathrm{UV})$ and $\mathrm{C}-\mathrm{TiO}_{2}(200)$ are rather stable when used as photocatalysts and there is no loss of photocatalytic activity after at least five cycles of degradation testing of MB.

Considering that $\mathrm{MB}$ can absorb visible light above $600 \mathrm{~nm}$ (the absorption peak is at about $665 \mathrm{~nm}$ ), a cutoff filter $(\lambda>600 \mathrm{~nm})$ was used to ensure that only $\mathrm{MB}$ was excited during the photocatalysis process. Whereas the photocatalysts we used nearly do not absorb the visible light with a wavelength longer than $600 \mathrm{~nm}$. With the use of the cutoff filter, no significant change in $\mathrm{MB}$ concentration was observed for the photocatalytic reaction even after $4 \mathrm{~h}$ irradiation in the presence of $\mathrm{C}-\mathrm{TiO}_{2}(\mathrm{UV})$ or $\mathrm{C}-\mathrm{TiO}_{2}(200)$. This observation indicates that the decoloration of $\mathrm{MB}$ under visible light with use of cutoff filter $(\lambda>420 \mathrm{~nm})$ is attributed to the photocatalytic effect of the obtained C-doped $\mathrm{TiO}_{2}$ samples, rather than $\mathrm{MB}$ photosensitization. 


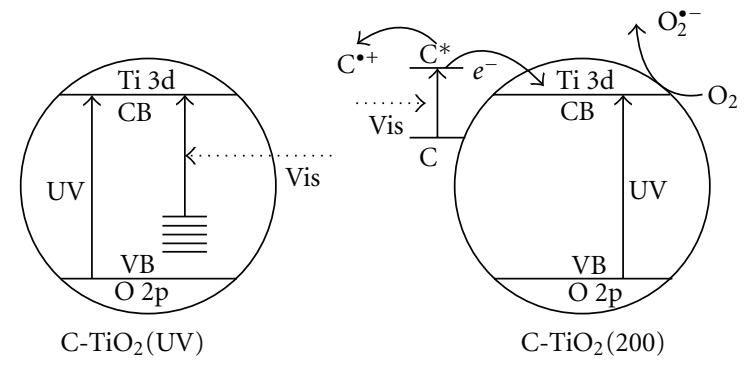

Scheme 1: The photocatalytic mechanisms for $\mathrm{C}-\mathrm{TiO}_{2}(\mathrm{UV})$ and C$\mathrm{TiO}_{2}(200)$.

3.5. Photocatalytic Mechanism. The carbon species in C$\mathrm{TiO}_{2}(\mathrm{UV})$ and $\mathrm{C}-\mathrm{TiO}_{2}(200)$ are very different in nature, and therefore, they contribute to the photocatalytic performances of the corresponding materials in different manners (Scheme 1).

For $\mathrm{C}-\mathrm{TiO}_{2}(\mathrm{UV})$, the carbons are incorporated in the $\mathrm{TiO}_{2}$ lattice to form Ti-O-C bonds. As demonstrated earlier by the UV-Vis spectroscopy, the electron transitions from the localized states associated with these $\mathrm{Ti}-\mathrm{O}-\mathrm{C}$ bonds to the $\mathrm{TiO}_{2}$ conduction band absorb visible light, and hence generating electrons and holes upon visible-light irradiation. The photogenerated electrons on the conduction band of $\mathrm{TiO}_{2}$ interact with $\mathrm{O}_{2}$ molecules to form oxidative species such as superoxide radicals which degrade the $\mathrm{MB}$ molecules.

For $\mathrm{C}-\mathrm{TiO}_{2}(200)$, the photocatalytic mechanism differs to a certain extent. In this material, there exists coke on the surface of $\mathrm{TiO}_{2}$. As demonstrated previously in the literature $[30,44]$, the coke itself can be photoexcited under visiblelight irradiation, and the excited carbon species inject the photogenerated electrons into the conduction band of $\mathrm{TiO}_{2}$. The injected electrons move to the surface of the $\mathrm{TiO}_{2}$, where they are captured by $\mathrm{O}_{2}$ to form superoxide ions $\left(\mathrm{O}_{2}^{--}\right)$, which finally lead to the degradation of MB. In addition, the photogenerated holes located in coke can also directly oxidize and degrade $\mathrm{MB}$.

\section{Conclusions}

An unusual light-driven strategy is explored for the preparation of highly porous $\mathrm{C}$-doped $\mathrm{TiO}_{2}$. It has been demonstrated that the obtained material exhibits high efficiency in visible-light photocatalysis for degradation of methylene blue. The carbon species, which are responsible for the visible-light photocatalytic activity, in the porous $\mathrm{C}-\mathrm{TiO}_{2}$ are found to exist in the form of $\mathrm{Ti}-\mathrm{O}-\mathrm{C}$ bonds. The Ti-O$\mathrm{C}$ bonds are thermally nonstable and can be transformed to coke matter after mild thermal treatment at $200^{\circ} \mathrm{C}$. The resulting coke-containing $\mathrm{TiO}_{2}$ is proved to be an even better visible-light photocatalyst, almost twice as effective as $\mathrm{N}$ $\mathrm{TiO}_{2}$. Our experiments reveal that both the $\mathrm{Ti}-\mathrm{O}-\mathrm{C}$ bonds and the coke species play a role in visible-light photocatalysis, providing new insights into the origin of visible-light photocatalytic performance of $\mathrm{C}-\mathrm{TiO}_{2}$ materials. Moreover, the strategy reported here is anticipated to open vistas for lightdriven preparation of inorganic materials with advanced functions.

\section{Acknowledgments}

This paper was financially supported by the National Basic Research Program of China (2007CB613303), the National Natural Science Foundation of China. The authors thank Mingyi Guo for TEM measurement.

\section{References}

[1] M. R. Hoffmann, S. T. Martin, W. Choi, and D. W. Bahnemann, "Environmental applications of semiconductor photocatalysis," Chemical Reviews, vol. 95, no. 1, pp. 69-96, 1995.

[2] X. Chen and S. S. Mao, "Titanium dioxide nanomaterials: synthesis, properties, modifications and applications," Chemical Reviews, vol. 107, no. 7, pp. 2891-2959, 2007.

[3] R. Asahi, T. Morikawa, T. Ohwaki, K. Aoki, and Y. Taga, "Visible-light photocatalysis in nitrogen-doped titanium oxides," Science, vol. 293, no. 5528, pp. 269-271, 2001.

[4] W. Zhao, W. Ma, C. Chen, J. Zhao, and Z. Shuai, "Efficient degradation of toxic organic pollutants with $\mathrm{Ni}_{2} \mathrm{O}_{3} / \mathrm{TiO}_{2-x} \mathrm{~B}_{x}$ under visible irradiation," Journal of the American Chemical Society, vol. 126, no. 15, pp. 4782-4783, 2004.

[5] H. Luo, T. Takata, Y. Lee, J. Zhao, K. Domen, and Y. Yan, "Photocatalytic activity enhancing for titanium dioxide by codoping with bromine and chlorine," Chemistry of Materials, vol. 16, no. 5, pp. 846-849, 2004.

[6] G. Liu, Y. Zhao, C. Sun, F. Li, G. Q. Lu, and H. M. Cheng, "Synergistic effects of $\mathrm{B} / \mathrm{N}$ doping on the visiblelight photocatalytic activity of mesoporous $\mathrm{TiO}_{2}$," Angewandte Chemie-International Edition, vol. 47, no. 24, pp. 4516-4520, 2008.

[7] W. Ho, J. C. Yu, and S. Lee, "Synthesis of hierarchical nanoporous F-doped $\mathrm{TiO}_{2}$ spheres with visible light photocatalytic activity," Chemical Communications, no. 10, pp. 11151117, 2006.

[8] D. Mitoraj and H. Kisch, "The nature of nitrogen-modified titanium dioxide photocatalysts active in visible light," Angewandte Chemie-International Edition, vol. 47, no. 51, pp. 9975-9978, 2008.

[9] G. Liu, Z. Chen, C. Dong et al., "Visible light photocatalyst: iodine-doped mesoporous titania with a bicrystalline framework," Journal of Physical Chemistry B, vol. 110, no. 42, pp. 20823-20828, 2006.

[10] S. U. M. Khan, M. Al-Shahry, and W. B. Ingler, "Efficient photochemical water splitting by a chemically modified n$\mathrm{TiO}_{2}$," Science, vol. 297, no. 5590, pp. 2243-2245, 2002.

[11] J. H. Park, S. Kim, and A. J. Bard, "Novel carbon-doped $\mathrm{TiO}_{2}$ nanotube arrays with high aspect ratios for efficient solar water splitting," Nano Letters, vol. 6, no. 1, pp. 24-28, 2006.

[12] J. Graciani, Y. Ortega, and J. F. Sanz, "Carbon doping of the $\mathrm{TiO}_{2}$ (110) rutile surface. A theoretical study based on DFT," Chemistry of Materials, vol. 21, no. 8, pp. 1431-1438, 2009.

[13] K. Yang, Y. Dai, B. Huang, and M. Whangbo, "Density functional characterization of the visible-light absorption in substitutional C-anion- and C-cation-doped $\mathrm{TiO}_{2}$," Journal of Physical Chemistry C, vol. 113, no. 6, pp. 2624-2629, 2009.

[14] B. Neumann, P. Bogdanoff, H. Tributsch, S. Sakthivel, and H. Kisch, "Electrochemical mass spectroscopic and surface photovoltage studies of catalytic water photooxidation by undoped and carbon-doped titania," Journal of Physical Chemistry B, vol. 109, no. 35, pp. 16579-16586, 2005. 
[15] H. Liu, A. Imanishi, and Y. Nakato, "Mechanisms for photooxidation reactions of water and organic compounds on carbon-doped titanium dioxide, as studied by photocurrent measurements," Journal of Physical Chemistry C, vol. 111, no. 24, pp. 8603-8610, 2007.

[16] C. Xu, R. Killmeyer, M. L. Gray, and S. U. M. Khan, "Photocatalytic effect of carbon-modified $\mathrm{n}-\mathrm{TiO}_{2}$ nanoparticles under visible light illumination," Applied Catalysis B, vol. 64, no. 3-4, pp. 312-317, 2006.

[17] G. Wu, T. Nishikawa, B. Ohtani, and A. Chen, "Synthesis and characterization of carbon-doped $\mathrm{TiO}_{2}$ nanostructures with enhanced visible light response," Chemistry of Materials, vol. 19, no. 18, pp. 4530-4537, 2007.

[18] Y. Park, W. Kim, H. Park, T. Tachikawa, T. Majima, and W. Choi, "Carbon-doped $\mathrm{TiO}_{2}$ photocatalyst synthesized without using an external carbon precursor and the visible light activity," Applied Catalysis B, vol. 91, no. 1-2, pp. 355-361, 2009.

[19] E. M. Rockafellow, X. Fang, B. G. Trewyn, K. Schmidt-Rohr, and W. S. Jenks, "Solid-state ${ }^{13} \mathrm{C}$ NMR characterization of carbon-modified $\mathrm{TiO}_{2}$," Chemistry of Materials, vol. 21, no. 7, pp. 1187-1197, 2009.

[20] H. Kamisaka, T. Adachi, and K. Yamashita, "Theoretical study of the structure and optical properties of carbon-doped rutile and anatase titanium oxides," Journal of Chemical Physics, vol. 123, no. 8, Article ID 084704, 9 pages, 2005.

[21] S. Sakthivel and H. Kisch, "Daylight photocatalysis by carbon-modified titanium dioxide," Angewandte ChemieInternational Edition, vol. 42, no. 40, pp. 4908-4911, 2003.

[22] Z. Liu, D. D. Sun, P. Guo, and J. O. Leckie, "One-step fabrication and high photocatalytic activity of porous $\mathrm{TiO} 2$ hollow aggregates by using a low-temperature hydrothermal method without templates," Chemistry-A European Journal, vol. 13, no. 6, pp. 1851-1855, 2007.

[23] X. Wang, J. C. Yu, C. Ho, Y. Hou, and X. Fu, "Photocatalytic activity of a hierarchically macro/mesoporous titania," Langmuir, vol. 21, no. 6, pp. 2552-2559, 2005.

[24] H. Li, Z. Bian, J. Zhu et al., "Mesoporous titania spheres with tunable chamber stucture and enhanced photocatalytic activity," Journal of the American Chemical Society, vol. 129, no. 27, pp. 8406-8407, 2007.

[25] Z. Bian, J. Zhu, S. Wang, Y. Cao, X. Qian, and H. Li, "Self-assembly of active $\mathrm{Bi}_{2} \mathrm{O}_{3} / \mathrm{TiO}_{2}$ visible photocatalyst with ordered mesoporous structure and highly crystallized anatase," Journal of Physical Chemistry C, vol. 112, no. 16, pp. 6258-6262, 2008.

[26] F. Dong, H. Wang, and Z. Wu, "One-step "Green" synthetic approach for mesoporous C-doped titanium dioxide with efficient visible light photocatalytic activity," Journal of Physical Chemistry C, vol. 113, no. 38, pp. 16717-16723, 2009.

[27] D. E. Gu, Y. Lu, B. C. Yang, and Y. D. Hu, "Facile preparation of micro-mesoporous carbon-doped $\mathrm{TiO}_{2}$ photocatalysts with anatase crystalline walls under template-free condition," Chemical Communications, no. 21, pp. 2453-2455, 2008.

[28] W. Wang, Z. Wu, and Y. Liu, "A simple two-step template approach for preparing carbon-doped mesoporous $\mathrm{TiO}_{2}$ hollow microspheres," Journal of Physical Chemistry C, vol. 113, no. 30, pp. 13317-13324, 2009.

[29] Y. Huang, W. Ho, S. Lee, L. Zhang, G. Li, and J. C. Yu, "Effect of carbon doping on the mesoporous structure of nanocrystalline titanium dioxide and its solar-light-driven photocatalytic degradation of $\mathrm{NO}_{x}$," Langmuir, vol. 24, no. 7, pp. 3510-3516, 2008.
[30] C. Lettmann, K. Hildenbrand, H. Kisch, W. Macyk, and W. F. Maier, "Visible light photodegradation of 4-chlorophenol with a coke-containing titanium dioxide photocatalyst," Applied Catalysis B, vol. 32, no. 4, pp. 215-227, 2001.

[31] J. A. Toledo-Fernández, R. Mendoza-Serna, V. MoralesFlórez et al., "Aerogels with applications in biomedicine and environment," Boletin de la Sociedad Espanola de Ceramica y Vidrio, vol. 46, no. 3, pp. 138-144, 2007.

[32] X. X. Zou, G. D. Li, K. X. Wang, L. Li, J. Su, and J. S. Chen, "Light-induced formation of porous $\mathrm{TiO}_{2}$ with superior electron-storing capacity," Chemical Communications, vol. 46, no. 12, pp. 2112-2114, 2010.

[33] X. X. Zou, G. D. Li, M. Y. Guo et al., "Heterometal alkoxides as precursors for the preparation of porous $\mathrm{Fe}$ - and $\mathrm{Mn}-\mathrm{TiO}_{2}$ photocatalysts with high efficiencies," Chemistry-A European Journal, vol. 14, no. 35, pp. 11123-11131, 2008.

[34] Y. Wu, H. Liu, J. Zhang, and F. Chen, "Enhanced photocatalytic activity of nitrogen-doped titania by deposited with gold," Journal of Physical Chemistry C, vol. 113, no. 33, pp. 14689-14695, 2009.

[35] Y. Li, D. S. Hwang, N. H. Lee, and S. J. Kim, "Synthesis and characterization of carbon-doped titania as an artificial solar light sensitive photocatalyst," Chemical Physics Letters, vol. 404, no. 1-3, pp. 25-29, 2005.

[36] J. P. Lange, A. Gutsze, and H. G. Karge, "Coke formation through the reaction of olefins over hydrogen mordenite. I. EPR measurements under static conditions," Journal of Catalysis, vol. 114, no. 1, pp. 136-143, 1988.

[37] H. G. Karge, J. P. Lange, A. Gutsze, and M. Łaniecki, "Coke formation through the reaction of olefins over hydrogen mordenite. II. In situ EPR measurements under on-stream conditions," Journal of Catalysis, vol. 114, no. 1, pp. 144-152, 1988.

[38] C. L. Pieck, E. L. Jablonski, J. M. Parera, R. Frety, and F. Lefebvre, "Characterization of residual coke during burning," Industrial and Engineering Chemistry Research, vol. 31, no. 4, pp. 1017-1021, 1992.

[39] C. D. Valentin, G. Pacchioni, and A. Selloni, "Theory of carbon doping of titanium dioxide," Chemistry of Materials, vol. 17, no. 26, pp. 6656-6665, 2005.

[40] A. Mills and J. Wang, "Photobleaching of methylene blue sensitised by $\mathrm{TiO}_{2}$ : an ambiguous system?" Journal of Photochemistry and Photobiology A, vol. 127, no. 1-3, pp. 123-134, 1999.

[41] W. Morales, M. Cason, O. Aina, N. R. De Tacconi, and K. Rajeshwar, "Combustion synthesis and characterization of nanocrystalline $\mathrm{WO}_{3}$," Journal of the American Chemical Society, vol. 130, no. 20, pp. 6318-6319, 2008.

[42] Y. C. Hsu, H. C. Lin, C. W. Lue, Y. T. Liao, and C. M. Yang, "A novel synthesis of carbon-coated anatase nanocrystals showing high adsorption capacity and photocatalytic activity," Applied Catalysis B, vol. 89, no. 3-4, pp. 309-314, 2009.

[43] H. Zhang, X. Lv, Y. Li, Y. Wang, and J. Li, "P25-graphene composite as a high performance photocatalyst," ACS Nano, vol. 4, no. 1, pp. 380-386, 2010.

[44] X. Yang, C. Cao, K. Hohn et al., "Highly visible-light active Cand V-doped $\mathrm{TiO}_{2}$ for degradation of acetaldehyde," Journal of Catalysis, vol. 252, no. 2, pp. 296-302, 2007. 


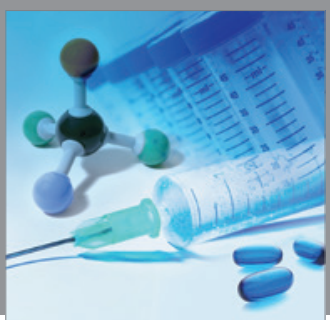

International Journal of

Medicinal Chemistry

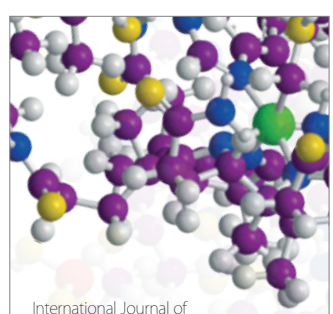

Carbohydrate Chemistry

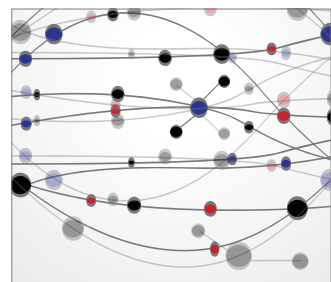

The Scientific World Journal
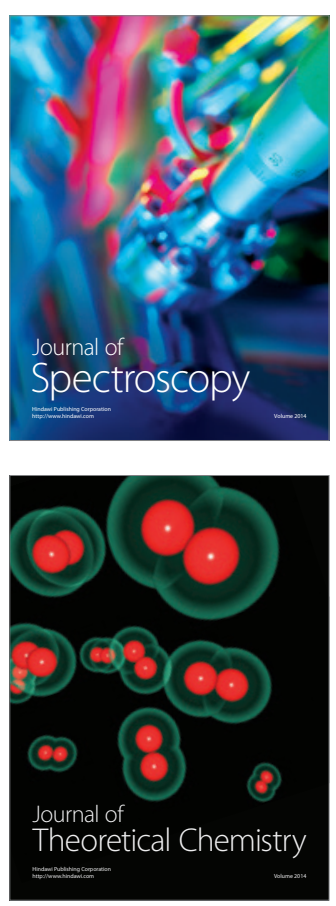
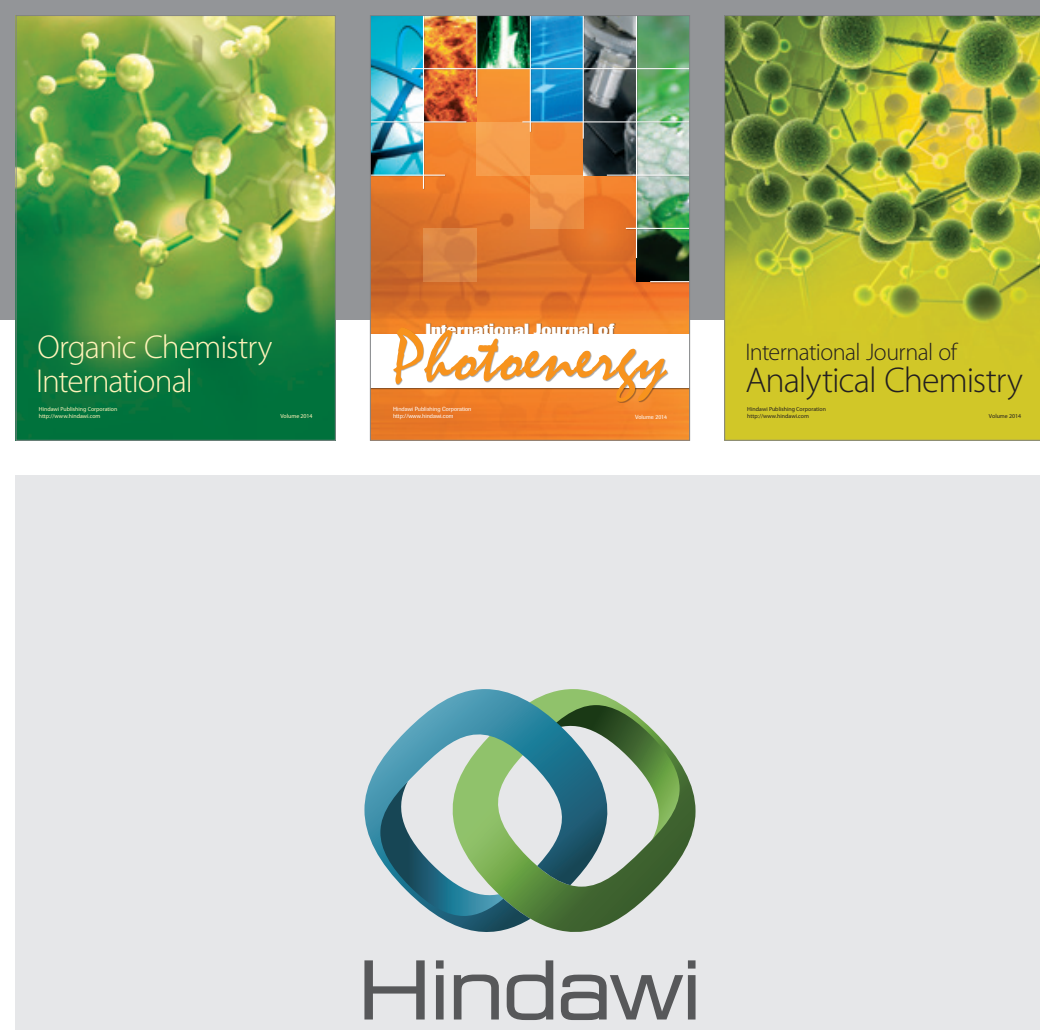

Submit your manuscripts at

http://www.hindawi.com
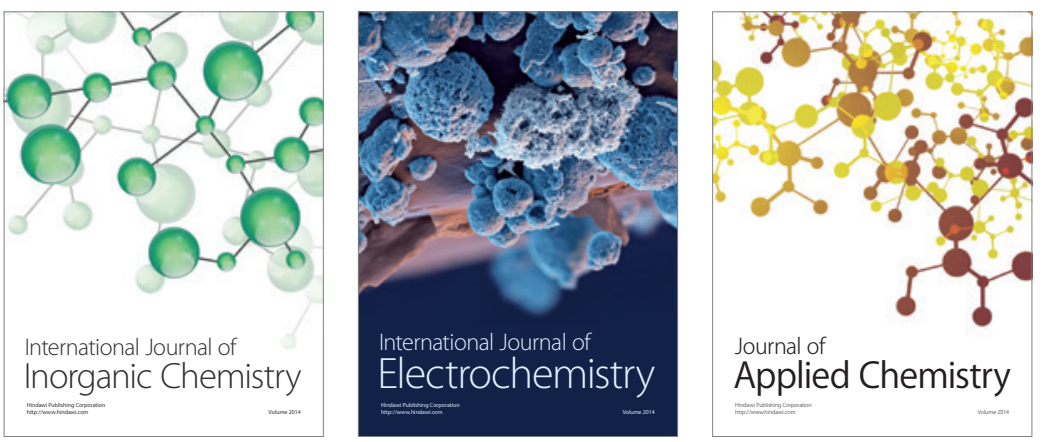

Journal of

Applied Chemistry
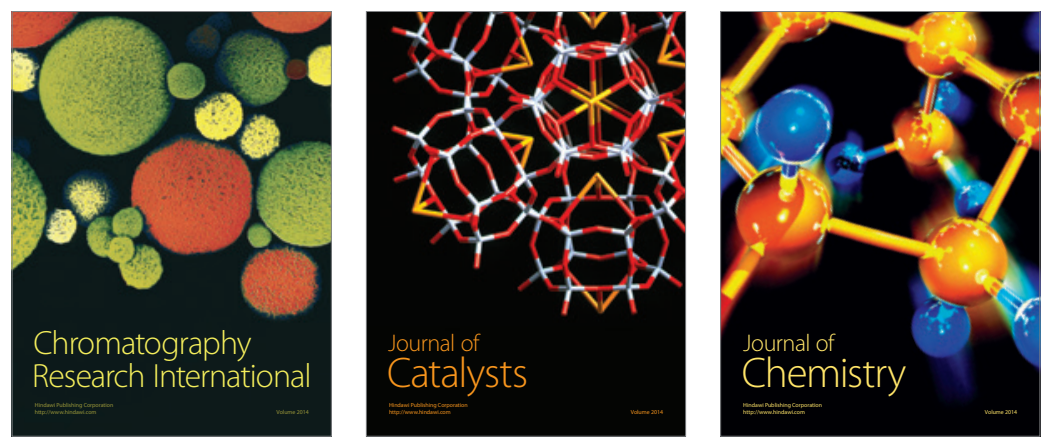
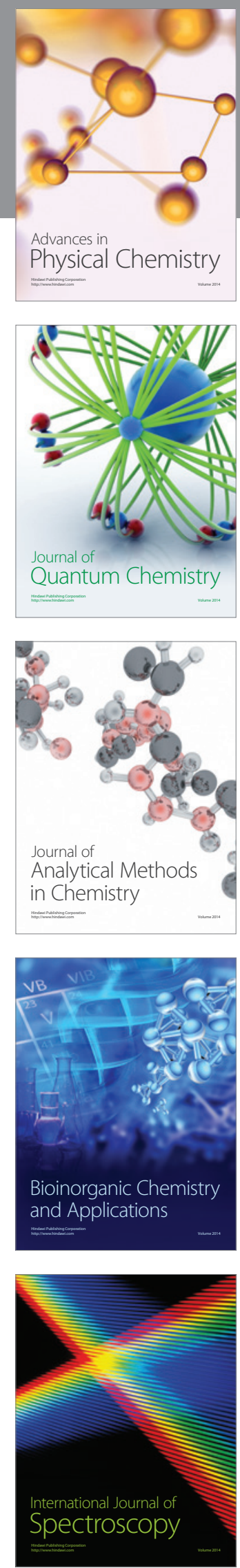